\title{
LOS CUENTOS SURREALISTAS DE MUÑOZ ROJAS
}

\author{
María Cecilia Ferreira Prado \\ Universitat de les Illes Balears
}

\section{RESUMEN}

No existen casi estudios sobre los Cuentos surrealistas (1979) de José Antonio Muñoz Rojas, autor más conocido por su labor poética en la postguerra española. Los cuentos fueron escritos, en su mayoría, por los años 30, momento de auge para el surrealismo español. El autor decidió publicarlos en su conjunto muchos años después. Debido a su gran visualidad y el rasgo humorístico, la obra recuerda el tono despreocupado y jovial de la primera vanguardia; sin embargo, se aleja de esta por la gran profundidad de pensamiento que expresa Muñoz Rojas en estos relatos. El presente estudio tiene por meta analizar los cuentos en su contexto, identificando los temas, motivos y técnicas surrealistas, así como sus rasgos estilísticos dominantes y las posibles influencias de otros autores.

Palabras Clave: surrealismo, vanguardia, narrativa espańola, Muñoz Rojas.

\section{CUENTOS SURREALISTAS BY MUÑOZ ROJAS}

\section{Abstract}

There are almost no studies on the Cuentos surrealistas (1979) by José Antonio Muñoz Rojas, author best known for his poetic work in the Spanish post-war period. His stories were mostly written in the 1930s, the time of the rise of Spanish surrealism. The author published them as a whole many years later. Due to its great visuality and humorous trait, the work recalls the carefree and jovial tone of the first avant-garde; however, he moves away from this because of the great depth of thought that Muñoz Rojas expresses in these stories. The objective of this study is to analyze the stories in their context, identify the surreal themes, motifs and techniques, as well as their dominant stylistic features and the posible influences of other authors.

KeYwords: surrealism, avant-garde, Spanish narrative, Muñoz Rojas. 
No deja de ser sorprendente que Muñoz Rojas, autor más conocido por su labor poética en la postguerra española, aunque también cultivó la prosa, publicara unos Cuentos surrealistas (1979), breves, a menudo calificados de prosa poética, en un momento en que, tal como indica el autor en el prólogo a la obra ${ }^{1}$, «se respiran tan distintos aires» $(11)^{2}$. Sin embargo, aclara luego, en la época en que los escribió «estaba al día el surrealismo y esto puede ayudar a entenderlos» ${ }^{3}$. Fueron muchos los poetas del Grupo del 27 que se sumaron a la nueva tendencia (Lorca, Alberti, Aleixandre, Cernuda, entre otros), aunque, curiosamente, y pese a que las obras de los surrealistas eran leídas con interés, muy pocos reconocieron la influencia francesa. Muñoz Rojas sí la asume, al menos, en parte:

Vicente [Aleixandre] me dijo que había que leer los Cantos de Maldoror, de Lautréamont, suscribirse a la Revolution Surrealiste y oír reverente a Breton y cofrades, sin que, la verdad, acabaran de calarle a uno como le calaron otras cosas. El bueno de José María Hinojosa predicaba lo mismo (12).

Y, así, no dejó de titular dicho conjunto de relatos como Cuentos surrealistas, aunque, paradójicamente, no estaba muy seguro de tal definición: «Si son surrealistas o no es cosa de dilucidar», duda que parece aceptable desde que los cuentitos no responden a un automatismo a priori. No obstante, los relatos surgen en ese momento de esplendor surrealista, de influjo de la vanguardia que, en su poesía, se inicia con Versos de retorno (1929) y alcanza una mayor madurez en Ardiente jinete (1931), de tema amoroso, Así, Antonio Lucas (2009: 1) elogia y reivindica la «tentativa lúdica de unos cuentos primerizos y ya firmes, burlones y líricos de los que casi nadie se acuerda». Dada la larga demora de algunas publicaciones, no parece que nuestro autor estuviera muy interesado en comercializar su obra. RuizCopete (2001: 161) indica su marginación y Fernando Ortiz (1982: 124) ve «que las causas que propician el desconocimiento de la obra [...] son, a su vez, rasgos esenciales e inherente a ésta». El olvido es patente y se constata también en la casi total ausencia de estudios críticos, artículos, monografías, reseñas, etc., que aborden estos relatos, que, por un lado, resultan anacrónicos en el tiempo de publicarse, tal como se indicó, pero, por otro, se advierten también extraños e inconexos dentro del propio universo prosístico y poético del autor, que incursionó, en general, en otras modalidades estilísticas.

Cuando Muñoz Rojas entra en la escena narrativa, casi han terminado su producción, lógicamente, entre otros, los autores consagrados de la generación de fin de siglo como Valle-Inclán y Unamuno o Baroja, quien, más joven, les sobre-

${ }^{1}$ En el prólogo de la obra: «Palabras a Nancy, que guardó estos cuentos».

2 Se cita por la edición indicada en la bibliografía, Cuentos surrealistas.

3 Algunos de estos cuentos se publicaron en revistas de los años 30. «Primera maravilla de los viajeros», en Los Cuatro Vientos (1933), y «Viento y fuego en la visita», en «El Aviso» de Cruz y Raya (1935). «El suicidio de un jesuita», en Nueva Poesía (1935). "Active Dust», el único posterior a 1940, en Finisterre (1948). 
vivirá veinte años. Están publicando los narradores del grupo intermedio, entre los que se podrían destacar, por sus prosas, a Miró, Pérez de Ayala y Gómez de la Serna, tan importante para la vanguardia de la época. Y, por último, los novelistas ya propiamente vanguardistas como Benjamín Jarnés, en concreto Teoría del zumbel (1930), donde presenta su mayor experimentalismo e imaginación surrealista; Mario Verdaguer, con sus novelas vanguardistas: El marido, la mujer y la sombra (1927), La mujer de los cuatro fantasmas (1931), Un intelectual y su carcoma (1934); la primera narrativa vanguardista de Antonio Espina con obras como Pájaro pinto (1927), una de cuyas técnicas sobresalientes son las imágenes y juegos dadaístas; y Agustín Espinosa, cuya novela Crimen (1934) es considerada, junto a las prosas poéticas de La flor de Californía de José María Hinojosa (1928), como la más representativa del surrealismo en España. El primer poemario de Muñoz Rojas, Versos de retorno (1929), recibe dicho influjo, a la vez que posee tantos rasgos de la poesía pura como del neopopularismo. No en balde, algunos críticos consideran a nuestro autor del 27, pues ofrece unas etapas literarias semejantes a esos poetas; sin embargo, por edad y también debido a otras cuestiones literarias, se suele asimilar al grupo de 1936. Asimismo, en su siguiente poemario, Ardiente jinete (compuesto en 1931, publicado en 1984), se percibe «la huella vanguardista: purismo, creacionismo, surrealismo [...], hasta el punto de que García-Posada afirma que quizás no habría sido posible sin Jacinta, la pelirroja (1929) de José Moreno Villa» (Pedraza, F. y M. Rodríguez 2005: 299).

Respecto a los Cuentos surrealistas, el libro está lleno de aciertos: sencillez expresiva y, no obstante, selección de vocablos sugerentes; atmósfera vagarosa y festiva; imágenes alucinadas y perplejidad constante; profundidad e inteligencia en los planteamientos; tono despreocupado y lúdico, teñido asimismo de nostalgia. Y, quizás, como reconoce el autor, destaca por encima de todo esa «ingenuidad total con que están escritos», un encanto especial, sello del propio Muñoz Rojas, que, unido al rasgo disparatado y eminentemente visual que dimanan, recuerda, en algún aspecto, a Ramón Gómez de la Serna, sobre todo en lo que concierne a la creación de greguerías; a José María Hinojosa con su río imparable de imágenes, aunque, por supuesto, sin ese automatismo verbal tan marcado; y también, muy especialmente, a una poetisa y novelista francesa, Lise Deharme, asociada al grupo surrealista de Breton y autora de Le poids d'un oiseaux, libro de cuentos de entidad onírica, que contaba además con ilustraciones de Leonor Fini.

Por lo demás, los cuentos rebosan de una espontaneidad y de una plasticidad visual que los acerca a los primeros cuentos infantiles, aunque con un sesgo poético y una hondura que los diferencia de aquellos.

"Primera maravilla de los viajeros» nos introduce en la aventura de un extraño viaje, íntimo, sugerente y revelador, cuyos personajes, argumento y tiempo, siguiendo la tónica del subtítulo, «Sin quién, ni cómo, ni cuándo», quedan vedados en la atmósfera de total extrañeza que impregna todo el relato. Díez de Revenga (2005: 290) señala el carácter de "un texto onírico y presurreal, en el que los objetos, los personajes y los paisajes muestran decididamente un mundo nuevo». Los protagonistas son seres indeterminados, desconocidos entre sí, contentos de no saber a dónde van, ni por qué viajan. Designados con los generalizadores pronombres: «él», 
«ella», «nosotros», atraviesan a pie largas distancias de una geografía natural arcádica; lo que da lugar al encuentro casual con seres sobrenaturales, marginales o atípicos. Estos encuentros, azarosos, no buscados, recuerdan las preguntas que hacían Breton y Éluard en la revista Minotauro: «¿Cuál ha sido el encuentro capital de su vida?» (Breton, A. y Paul Éluard 1933: 101), y estructuran el relato mediante una yuxtaposición de estampas que se asemejan a las vivencias de un sueño. El primer encuentro tiene lugar cuando se topan con un río, "presuntuoso y soberbio", que les impide el paso. "Ella» sortea el problema desafiando al río a que circule por su seno. El segundo es con la locomotora, emblema de una civilización racionalista, que interrumpe la despreocupada vida campestre, causando miedo y desconcierto. El tercero se produce con los forajidos, cuatro ladrones de buenos sentimientos que, al igual que Guzmán de Alfarache, defienden la honradez de su oficio. Al ser muy conscientes de lo que son, ladrones, y no querer ser otra cosa, constituyen para los viajeros «el primer ejemplo de seres que sabían cumplir estrictamente con su deber y con su nombre» (22). Por último, el cuarto tiene cabida cuando encuentran a las «madres dolorosas» que han perdido a sus hijos y, «tomando a los viajeros por iluminados y profetas», les piden que los resuciten. El problema surge porque algunos de estos hijos carecen de nombre: «nuestros viajeros pensaron la tristeza de devolver los hijos a unas madres y a otras no. [...] y decidieron no resucitar a ninguno». El narrador comenta irónicamente que «Poco trabajo les costaba, si no, llamar al nombrado por su nombre y devolverlo a su madre», afirmación que incide en el poder mágico de la palabra e iguala a estos viajeros al nivel de los dioses, «Lo que no podían de ningún modo era llamar a quien no tiene nombre» (23).

Hay en toda la narración una reafirmación de la libertad, de la vida sencilla al aire libre, de un tiempo de ocio que permite gozar con los cinco sentidos, lejos de los servilismos y convencionalismos sociales. Pero, también, de la espontaneidad, que en ningún momento disminuye, ni siquiera ante la realidad tan acuciante del hambre o de la sed, que se resuelve en la ficción mediante una serie de imágenes poéticas, cercanas a las greguerías: "Como no comamos pedazos de sueño en este plato limpio del campo»; «Nuestro vino y nuestra agua serán unos vasos de sueño servido en la bandeja de la noche» y mediante una cena frugal consistente en las «espigas perdidas de los segadores» (18).

También, destaca esa exaltación de la naturaleza por contraposición al mundo moderno, que se evidencia en el encuentro con la locomotora. Si los primeros vanguardistas sintieron un casi fervor por los nuevos objetos y artefactos que traía la modernidad, ya con los surrealistas notamos ese recelo hacia la máquina, sospechosa de producir la alienación y mecanización en el hombre. La máquina, como un dios omnipotente, implacable, capaz de estremecer «a las muchachas que cosían" y parar el juego de las niñas, irrumpe en la paz del paraíso, y los viajeros se esconden, no quieren subirse al tren. Pero la locomotora insiste en llevarlos y pregunta por el equipaje, sus pertenencias, la cuestión material. Ellos «Señalaron los árboles y el cielo, la tarde y el campo, hasta los almendros que orlaban la vía, unas nubes recién estrenadas y blanquísimas» (20). La locomotora, imbuida del espíritu mercantilista del sistema que la ha creado, solo es capaz de referir motivos económicos: «-No encontraréis quien os lleve todo eso por un precio módico» (20). Pero los 
viajeros ya cuentan con un medio de transportar aquel paisaje espiritual que contemplan y que constituye su único y más valioso capital: los ojos que, como espejos del alma de la realidad, son portadores de grandes cosas.

El relato termina con un cuestionamiento de la realidad del mundo exterior por contraposición a la realidad del mundo interior, más intensa y consistente. «Escribe él. "¿Qué risa me dan las nubes imponentes o mansas, finas o compactas! Porque las nubes no son nubes verdaderas y apenas si llenan el cielo. En cambio, éstas de aquí dentro sí que son agobiantes y sobrecogedoras. Sí que anegan cuando llueven y no hay salvación ni consuelo"» (24). El tiempo ha pasado y la vida ha dejado su huella, un rastro doloroso en «Él», quien reconoce por otra parte no ser más que un simple viajero; de ahí la recomendación final dirigida al lector: «necesitáis olvido». Por su parte, el narrador, en la acotación final del párrafo sangrado, reconoce que se siente habitado y viajado por sus personajes; al mismo tiempo seńala la crisis que habría desencadenado la historia: «Todavía no ha concluido, como no empezó nunca la historia. Son estos temblores y fervores, estremecimientos y lágrimas, que se han refugiado en mí y a los que he abrigado cuidadosamente. Mis viajeros, embarcados en mi sangre, han recorrido todo mi cuerpo» (25).

La greguería final que cierra el relato, en boca de un niño, trae a su dolorido presente el mundo más amable de la infancia, y una reafirmación de los viejos sueños infantiles que se pierden tras llegar la adultez; así, el niño le advierte que «las estrellas eran gorriones inmóviles disfrazados de blanco y que él las derribaría alguna vez».

«Tres variaciones sobre el calor» son en realidad tres relatos autónomos, cada uno de los cuales ofrece una versión distinta sobre el motivo unificador de las altas temperaturas, causantes del deseo sexual, el sueño o la alucinación. Vittorio Bodini (1982: 30) afirma que el desafío surrealista consiste en «la promesa de ampliar prodigiosamente los límites de lo real mediante la penetración en los terrenos de la magia y del sueńo, la liberación de los tabúes, la supresión del umbral entre consciente e inconsciente», motivos todos que se constatan en las tres siguientes narraciones.

En «El calor, los caballeros y las damas», en medio de una aburrida reunión, marcada por el ritmo de los abanicos y el balanceo de las mecedoras, el calor resulta un agente transgresor en ese ambiente convencional y pacato, pues desata la nota erótica. Tanto ellos como ellas necesitan un motivo racional para desnudarse e intimar, y este motivo viene a ser el calor. Destaca el comportamiento lúdico de los personajes, regidos por la lógica del absurdo, con actitudes y diálogos sorprendentes. Ante algunas insinuaciones eróticas de las damas, «Si desnudas sobre la nieve...», imagen con la que evocando el frío pretendían atenuar el calor, paradójicamente, el calor se recrudece y los hombres se levantan para aproximarse a ellas. Sin embargo, de improviso, entra un viento por la ventana que desbarata el calor, de modo que a ellos no les queda más remedio que regresar a sus sitios. Lo mismo ocurre cuando tanto ellas como ellos comienzan a desnudarse, y a quitarse prendas alternativamente, la irrupción del airecillo fresco frena que se produzca el desnudo total: la frustración erótica es constante. El viento, personaje antagónico del calor, estropea a cada instante los deseos e intenciones de los hombres, causando las risitas discretas y cómplices de las damas, que resaltan con ironía: «y ya no había modo de apreciar la calidad de la nieve» (32). 
En la segunda estampa, "La sala, el niño y las muchachas», una habitación, decorada en un estilo trasnochado y cursi, acoge en su interior el hastío de dos jovencitas (que no paran de lamentarse del colegio) y del «niño, a quien habían olvidado de ir a buscar» (34). La espera, unida al calor, lleva a los tres personajes al diálogo intrascendente, una charla banal en medio de la cual el nińo, inocentemente, compara a una de ellas con un buey rubio, hecho que provoca el llanto de la joven. Se hace de noche y el niño se queda dormido, ellas también comienzan a adormilarse. Si antes se había animalizado el personaje, mediante una figura, el buey, que recuerda en cierta medida algún cuadro de Leonora Carrington, ahora se animaliza una situación temporal, la noche. La noche no es solo una dimensión espacial o temporal, gracias a su calor y a la intensidad de sus olores adquiere densidad y peso en el relato y se convierte, en sueños del niño, en el insecto que se posa sobre su frente. El niño sueña que sus manos crecen sobre los hombros de la joven y que "eran como caballos que galopaban» (36), distorsión alucinatoria que parece referir el desarrollo de un sueńo erótico. Pero luego esta escena se interrumpe para dar paso a la siguiente, en la que se produce el castigo moral, aparece la culpa, también en clave onírica, mediante la imagen de la mano desmembrada, mutilada; así, el niño halla «a su pequeña mano, sola, en un parque inmenso» (36); posteriormente, la mete en un jarro con agua, "mas no había metido la suya, sino la de otro niño que se despertaba llorando». El narrador distingue así el yo sońado del yo real, una distinción necesaria si tenemos en cuenta que no son lo mismo, aunque suelan confundirse a menudo. El sueño deja caer los disfraces, pone de relieve los verdaderos deseos, inquietudes y miedos del personaje. Tal como señala Paul Ilie (1982: 243):

Mientras la literatura tradicional ocultaba los elementos reprimidos de la naturaleza humana, la nueva función de la actividad onírica libera a la psiquis capacitándola para expresarse con absoluta fidelidad. Esta lealtad a la realidad garantiza el descubrimiento de las más altas leyes de la vida, aquellas que las defensas de la vigilia mantienen escondidas.

En relación con la mutilación del cuerpo, hay que asociarla a una técnica típicamente surrealista análoga al collage. Según Agustín Sánchez Vidal (1982: 66):

Es, pues, el extrańamiento lo que interesa como peldaño de acceso a la superrealidad. Y entonces comprendemos que la más sólida manera de lograrlo consiste en unir lo que es dispar (collage) o separar lo que está unido o es afín (mutilación). Collage y mutilación no son, por tanto, sino el haz y envés de una misma actitud a la búsqueda del extrañamiento que rompa con la neutralidad opaca y gris que ha llegado a adquirir lo cotidiano. [...] De hecho, a menudo la mutilación no es sino la operación previa al collage [...].

El tercer relato, «Viento y fuego en la visita», es quizás el más logrado, desde un punto de vista estilístico y argumental. La barba rubia de Asparagus, el protagonista, es como la vida misma: «Todo el mundo... esperaba que aquella sería una barba de nunca acabar» $y$, sin embargo, se interrumpe de manera abrupta «con una quebradura súbita y sin razón» (37), de ahí la comparación inevitable, 
asimismo, con la muerte: «Eran, pues, las barbas de Asparagus, muerte para los ojos» (37). Sin embargo, la barba atrae la mirada de las mujeres que no pueden evitar fijarse en ella e introducirse en sus muchos recovecos como pájaros que buscan su nido. El relato está lleno de metáforas que ahondan en un mundo onírico, extravagante. En uno de sus sueños a Asparagus le crecen las barbas hasta el mar, imagen hiperbólica relacionada con la virilidad del personaje, que contrasta con la barba rasurada del inicio. Se le van subiendo por ella peces con un anillo en la boca, peces que luego se transforman en mujeres que le piden casarse. Pero el personaje es reticente al matrimonio y a todas estas propuestas da una negativa, con la consiguiente protesta de las damas, que se manifiesta en cuchicheos y tosecitas. Parece que esta actitud es un rasgo constante y definitivo en el personaje porque el narrador da cuenta de "cómo ellas le pesaron a través de toda su existencia» (38). La elaborada alegoría onírica sirve de marco e introducción a la escena siguiente, en la que Asparagus se entrevista con cuatro señoritas idénticas, tal vez gemelas, «las señoritas de Esperanza», a las cuales «no había manera de distinguirlas» (38). Se trata, de nuevo, de una situación convencional, de unas maneras establecidas, marcadas por el ritual y las normas sociales: la elección de una de las cuatro doncellas como esposa. Asparagus entra en la habitación «dándose perfecta cuenta de la gravedad del momento" (39) y su desajuste, unido al intento de encajar en tal evento, se evidencia en la preocupación por abrocharse «el botón superior del chaleco» (39). Nada más saludarlas, se desata el conflicto en medio de una discusión en torno al amor, entendido este de manera abstracta por el protagonista, que es incapaz de decidirse por alguna de las mujeres. La inadaptación del personaje se acrecienta al pronunciar la frase inadecuada, la frase infame que rompe el protocolo: «-Y a vosotras, ¿cómo os gustaría amar? Asparagus no sabía lo que había hecho. Inocentemente había dicho aquello, sin sospechar que sus palabras iban a ser fuego sobre paja reseca» (40). La frase incómoda desencadena una serie de comportamientos histéricos en las mujeres, como si hubiera tocado la fibra más íntima del sentimiento, desatando los impulsos inconscientes: la primera irrumpe en llanto; la segunda baila al son de una música inaudible; la tercera, víctima de una alucinación, se cree un insecto sediento que cae en una fuente y se ahoga; la cuarta se desnuda. Finalmente, todas ellas se transforman en llamas, metáfora de larga tradición poética mediante la cual Muñoz Rojas pretende representar el efecto ardido de la pasión y sus consecuencias nefastas. Por suerte, igual que en el anterior relato, un viento, que entra por la ventana personificado en un joven musculoso (imagen de evocación lorquiana), desbarata el impulso erótico y vuelve todo a la normalidad; no sin antes dejar al descubierto los secretos y defectos de cada uno: así, al levantar las faldas de las señoritas, queda al descubierto la mojigatería de estas en los largos pantalones "con encajes a la altura de las rodillas». Por otra parte, el viento levanta y divide en dos las barbas de Asparagus, evidenciando la falta de distinción necesaria del caballero, que no solo no portaba corbata, sino que tampoco tenía corazón, lo que viene a coincidir con la alegoría onírica del principio, es decir, con su incapacidad para amar, para asumir el compromiso amoroso. Es evidente el rasgo marcadamente simbólico e irracional de este cuento; "lo cierto es que la mayoría de los textos surrealistas se presentan como un despliegue casi ininterrumpido de 
imágenes que ofrecen el carácter común, sean de la índole que sean, de desafiar al buen sentido" (Raymond 1983: 243).

El cuento siguiente, "Espadas como labios», es el homenaje que Muñoz Rojas realiza al poemario de título homónimo de su gran amigo Aleixandre, y recoge la concepción aleixandrina del amor equiparable a la muerte. Las primeras líneas muestran ya el carácter vanguardista del texto, mediante metáforas irracionales que relacionan el acto comunicativo entre dos amantes con el acto sexual. El protagonista, Amintore, deja caer sobre una joven que se halla en posición horizontal palabras que, materializadas en peces, la penetran por el orificio del oído: «las palabras son animales, peces en este caso, aves en cien otros, que de árbol en árbol se pasan la vida trazando signos» (45). Se introduce, luego, una nota de misterio: él no sabe su nombre. La característica más destacada de su prosopopeya es que posee «los labios finos como dagas» (46), lo que provoca en él a la vez atracción y rechazo y la tristeza de ella que, a causa de esta deformidad, se ve, de continuo, rechazada por la gente. Finalmente, Amintore vence su aversión y la besa, en ese momento se descubre la identidad de la joven, que al inicio del relato se había escamoteado al lector. El narrador informa que Amintore se siente «sorprendido de pronto por la vida, cuando en realidad la sorprendedora había sido la muerte» (49). Estamos ante la concepción aleixandrina de considerar el amor como destrucción (Bousoño 1968: 70).

"iAy!, dice el sauce» es, tal vez, el relato más extraño y surrealista. Narra el encuentro de una joven con un antiguo amor, un ángel, cuyas «alas se le habían caído» (53). El misterioso personaje, del cual nada se sabe, ahora viste de gris -lejano recuerdo de Sobre los ángeles de Rafael Alberti donde aparecen imágenes en las que las alas de los ángeles no cumplen su función voladora, así, entre otros, en los poemas «El ángel desconocido» $\mathrm{y}$ «Los dos ángeles»-. Los personajes, separados por una alta pared que parece materializarse en un sauce, se comunican con gran dificultad. Todo ello trae a la memoria el mito de Píramo y Tisbe, nomás sea por la pared y por el recurso de la voz, único medio de que disponen para relacionarse. Aquí, salvando todas las distancias, la morera de la fábula podría equiparse al sauce que, en lugar de moras, produce sonrisas y sollozos. Al actuar de intermediario, el árbol es testigo silencioso del extraño diálogo que se efectúa entre los dos enamorados, un diálogo en clave teñido de premoniciones y notas enigmáticas, que dejan al lector fuera de toda comprensión del texto: «Pero el tiempo no esperaba otra cosa que verlos cogerse las manos para echarse a correr» (56). Y finalmente, vencida por el tiempo, como suele ocurrir en la vida real, la pareja se separa: "Anduvieron un trecho y se dijeron adiós» (57).

El siguiente relato, «Laurel», asume también la forma de diálogo entre dos examantes que reconstruyen vagamente un día de tórrido calor en que él la besó a ella, una joven llamada Laurel. Así, se entabla una lucha dialéctica entre los dos personajes cuando el joven intenta hacerle recordar algo que ella preferiría olvidar; tal vez la culminación amorosa, metaforizada sutilmente en el canto de un ruiseñor. Sorprende cómo, con tan pocos elementos, la lucha por un abanico en el interior de una casa, la anécdota del pelo cayendo en cascada, la otra más trivial de la lluvia y el canto de un pájaro, Muñoz Rojas logra crear una ambientación mágica e irreal llena de gracia y espontaneidad. De un modo similar a como ocurre en ante- 
riores relatos, para evitar el calor, los personajes crean algunas imágenes refrescantes, así el joven sugiere: "Se me ocurre que para dejar de tener calor debieras soltarte el cabello". Así lo hiciste. Cayó como un torrente negro por tus espaldas, sonando como un torrente cuando se despeña. “QQué escalofríos! ¡Qué fría está!”, exclamabas» (63). Más tarde salen al jardín y los sorprende la lluvia, por lo que se refugian «en un hueco de la tapia» (64), esperando que el chaparrón cese para que pueda cantar el ruiseñor. Pero el ruiseñor solo canta tras la declaración amorosa de él, momento en que ocurre algo que se escamotea al lector, un incidente que ella no desea que él mencione, de ahí ese «Si lo dices me mato!» y el «Adiós!» final de ella, que se escapa para no seguir escuchando. Este relato, en concreto, crea vínculos con otro de entidad autobiográfica, "Mes de mayo", de Las musarañas, un texto que narra las vivencias infantiles de Muñoz Rojas, en este caso amorosas, mientras recorre el huerto de la mano de una nińa: «Y mi mano como un pájaro entre las tuyas, [...].

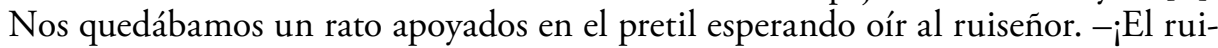
señor! ¡El ruiseñor!» (58) ${ }^{4}$. El rasgo simbólico del ave es evidente: tradicionalmente asociado a la llegada de la primavera, porque su canto aparece en el mes de mayo, suele simbolizar el amor y la juventud.

En «La prisa del amor», asistimos a la creación de un mundo maravilloso adentro del bastidor que borda Elvira, quien espera, como una Penélope moderna, a que regrese el hombre desconocido que cogió su sombrero y se marchó con prisa:

Ella volvió tristemente a su labor. Bordaba un árbol frutal -¿̨un peral, un ciruelo?, ni peral ni ciruelo. En las ramas iban y venían pájaros imprudentes, que adivinaron en la desgana con que la muchacha manejaba las agujas, toda la tragedia que suponía para su alma que el amor hubiera cogido su sombrero y se hubiera marchado (69).

El paisaje resulta una extensión de su conciencia y de sus diferentes estados anímicos. Tras descubrir que el hombre se ha olvidado el bastón -y por ende ha de volver-, y gracias a la pregunta de un pájaro bordado, el árbol comenzó a atiborrarse «de peras, de manzanas, de cerezas, de albarillos, frutas del país y tropicales, fresas plátanos, melocotones. Acudían los pájaros en bandadas enormes» (70), imagen con la que se pretende representar la felicidad de la joven.

La siguiente estampa narra el pasado del caballero, a través de la charla que mantiene con don Abundio, el dueño de su café favorito, el «Oso polar»: «-En cierta ocasión caí prisionero de unos piratas malayos. La esposa del capitán se encaprichó conmigo. Yo había jurado fidelidad conyugal y estaba decidido a guardarla a toda costa» (71). Esta breve anécdota resume el drama sentimental del héroe, quien tras la infidelidad queda solo, seco y lleno de culpa.

Mientras tanto "Elvira seguía esperando» y su desesperación se traspasa al lienzo con «una luna llena y tal vez demasiado amarilla para espantar a los pájaros nocturnos, que en gran número habían acudido al árbol» (72). El paisaje se vuelve

\footnotetext{
${ }^{4}$ Se cita por la edición de la bibliografía y entre paréntesis se indica la página.
} 
siniestro: «Triste era, en efecto, su suerte» (72). Una suerte marcada por la espera, rasgo caracterizador del personaje "-Esperar: he ahí mi destino». Con la venida de la noche, el árbol se llena de presencias, las ánimas, una rama se cae y la dama es sepultada por las frutas del árbol que ella misma había bordado. Finalmente, Abundio y el caballero la descubren muerta sobre el piso. La muerte junto al amor son temáticas centrales en este libro.

La picardía y el sentido agudo del humor se combinan perfectamente en este cuento, "Alicia y Ángel Resumen", que se basa en la singularidad del apellido para desencadenar la risa y provocar un distanciamiento de la anécdota sentimental: «Oyó claramente el apellido de él: Resumen. "Resumen ¿de qué?", se quedó Alicia pensando" (79). Otros recursos del humor son la cosificación y la caricatura: "Cuando se lo presentaron a Alicia le pareció ridículo. Mucha cabeza y poco cuerpo. Un tentempié al revés» (79). Pero la galantería del joven hace que Alicia reconsidere su impresión inicial: «La cabeza pasó de gorda a interesante, el cuerpo adquirió proporción. Los ojos cobraron fuego, la voz insinuación» (79-80). Cada vez que Ángel le habla, su voz la conduce por los caminos de la ensońación y se le olvida por completo su aspecto exterior. Lo imagina primero como un ángel custodio que la salva de caer al precipicio. Luego se figura a sí misma vestida de blanco. El joven parece participar de estas divagaciones porque ante la pregunta de Alicia «¿de qué flores llevaba yo el ramo?» (82), este le responde: «-De camelias», lo que causa el desmayo de Alicia, que, «para completar su felicidad, le preguntó: -Dime Ángel, Resumen ¿de qué? -Resumen Alfonso» (82-83). El cuento termina con una gracia final: «A Alicia se le vino el mundo a los pies. A los mismos pies en que yacía desplomado Ángel Resumen Alfonso» (83).

«Escribir Aurelio» se centra en una despedida en el puerto y en la evocación por parte del personaje femenino de los diálogos que mantenía con su antiguo amor, el hombre que la ha abandonado en la orilla. El cuento profundiza en todas las dimensiones del amor a distancia: la sensación de tiempo perdido que experimentan los amantes, el miedo a que la relación termine, el fantasma del olvido que planea sobre los dos. Para revertir la dolorosa situación, la joven lo amenaza con volverse loca y escribir en un papel eternamente su nombre, "Aurelio». A fin de acortar las distancias y sabedora del poder mágico del amor, le pide lo imposible: «Estoy sola todos los días en mi cuarto de cuatro a seis. Dejaré todas las puertas abiertas. Así llegarás más fácilmente» (91). Con la ilusión de este acontecimiento increíble logra, al menos, llenar y dotar de sentido a sus largas y vacías horas de espera.

«El suicidio de un jesuita» es un relato que expresa de forma alegórica el transcurso del día desde que sale el sol hasta que se pone y llega la noche. Y todo ello mediante la historia de amor entre el horizonte y Ellen, miss Horseback. Paralelamente, se producen las meditaciones religiosas de un jesuita que, momentos antes de suicidarse, intenta convertir al horizonte a la fe. Al igual que otros elementos de la naturaleza, el protagonista se halla en este cuento profundamente humanizado: «El horizonte era un personaje vestido casi siempre de rojo [...] ella lo veía venir exactamente como se fue. Unos días más rojo, otros más pálido, unos con impermeable y botas de agua, otros con zapatillas y batín anaranjado» (95). Mediante esta enumeración de colores y vestimentas se representan los distintos estados atmosfé- 
ricos, que describen los aspectos exteriores del horizonte. Sin embargo, a diferencia de su enamorada, "que tenía unos omoplatos durísimos, un durísimo amor» (98), el horizonte, mero límite entre distintas realidades, «no tenía cuerpo»; ello provoca la inseguridad de su novia y la angustia existencial del personaje, que se pregunta "qqué soy yo?» (95). Esta indefinición o vaciamiento de identidad facilita que se pueda amoldar a distintos elementos del paisaje tales como el vergel, el mar, el cielo o incluso las montañas, sin decidirse por ninguno. Todos estos elementos paisajísticos se encuentran espiritualizados, integrados y vistos desde una perspectiva dinámica que permite recorrerlos en toda su extensión. Mediante estas sugerentes fusiones crea el autor la sensación etérea, límpida de grandes distancias, que prevalece a lo largo del texto: «El horizonte se tiró al agua. ¿Estoy en el mar o en el cielo? Nadaba en el cielo. El cielo está compuesto de unos materiales que no ofrecen resistencia y que sin embargo sostienen». Luego añade: «Él era el mar sin límites» (97). Desde el mar supervisa al jesuita en la orilla, que ironiza sobre su destino final «-¿Dónde va usted, padre? -Me embarcaré dentro de unos instantes. Voy al lejano Cipango [...] -¿Qué se le ha perdido allí? Toda la respuesta fue una sonrisa. Unas graciosas gaviotas lo dieron a entender» (97). En una secuencia posterior, la presencia de la noche incita al encuentro amoroso del horizonte con miss Horseback, Ellen. "La noche estaba calurosa. Se sentaron en un banco; a poco se levantó Ellen para desnudarse» (98), y, como ocurre con la salida de la luna -o tal vez Ellen es la luna-, "Se iluminó la oscuridad con el resplandor del cuerpo desnudo» (98). Pero, por desgracia, la noche se siente capaz de "cometer una mala acción», por ello, «Algunos árboles piadosos se llevaron las manos a los ojos» (99). En efecto, la venida de la noche, como es obvio, resulta letal para el incauto horizonte, que deja de ser visible; así nos lo hace saber el narrador a través de una alegoría, imagen de claro sesgo lorquiano: «Ya no hubo tregua. La noche sacó la navaja de la liga y apuñaló al horizonte. Quedó su cuerpo tendido junto al agua, que fue lavando las heridas. Ellen recogió su ropa y siguió desnuda y silenciosa a la noche» (99).

«Active dust» narra en tiempo presente el encuentro (o desencuentro) del narrador con su tío Ricardo en un coqueto restaurante inglés. El tío, solterón empedernido en su juventud, ahora está casado. No solo no le presenta a su mujer, sentada a su lado, sino que tampoco parece reconocerlo. Este último hecho, unido a la presencia del polvo que lo cubre todo, «Un polvo negro sobre el mantel, sobre el pan, sobre las coles de Bruselas. Polvo, polvo, pero activísimo, sin parar, extendiéndose, llegando a todas partes» (103), son los dos puntales con los que Muñoz Rojas entreteje su atmósfera de estupor y perplejidad. A ello se suma la casi ausencia del personaje protagonista, quien, enigmáticamente, no es visto ni escuchado por ninguno de los comensales. La conversación gira en torno a la mala calidad de la comida. Aquí, como en otras ocasiones, los alimentos dan pie al autor para desarrollar una serie de greguerías: «La sopa era engrudo, el cordero había pastado en el Paraíso y la tarta de manzana era tan vieja como la manzana sin tarta de Eva» (103). Por otro lado, como es propio en una narración vanguardista, y más aún en una que se precie de surrealista, abunda en este cuento el recurso de la animalización. Así, el frac largo del camarero, cuya cola se le mete entre las piernas y le impide caminar correctamente, lleva a que el narrador lo compare con un gato que corre y se sube a 
los árboles. El cuento termina con las dos notas de extrańamiento del principio: la indiferencia del tío Ricardo hacia su sobrino y el polvo, que aquí simboliza la capacidad de degradación que, sobre todas las cosas, incluso aquellas que representan un principio vital como la comida, ejerce el tiempo, un tiempo capaz de acabar hasta con los recuerdos más queridos y entrańables.

\section{CONCLUSIÓN}

Sin duda una cuestión fundamental es la calificación o definición de estos cuentos, por otra parte, singulares en la prosa de Muñoz Rojas. Parece esencial tener en cuenta la paradoja que subyace en el pensamiento de Muñoz Rojas cuando, por un lado, duda de su adscripción surrealista, como hicieron tantos escritores españoles del periodo, algunos negando tajantemente cualquier vinculación al movimiento, y, por otro, otorga a sus cuentos el calificativo de surrealistas, en el título de la obra.

Evidentemente, los relatos no responden a la técnica de la escritura automática, exigida por André Breton en el Primer Manifiesto; no obstante, esta circunstancia no es óbice para que no puedan considerarse surrealistas en un sentido más amplio, al menos en lo que respecta a otras técnicas empleadas por el autor o incluso al contenido. Así, gran parte de ellos tienen como finalidad la consecución de cierto esteticismo surgido de los motivos oníricos o inconscientes que, produciendo gran desconcierto en el lector -efecto típico del arte surrealista-, salpican toda la obra. La mayoría de estos motivos, de rasgo eminentemente simbólico, fueron abordados, asimismo, por los grandes poetas, pintores y cineastas de la época: la mano mutilada, los cuerpos en llamas, las personas con rostro de animal o con apariencia de objeto, las visiones alucinadas, el sueño erótico, las metamorfosis increíbles, los elementos mágicos y sobrenaturales, etc. Por otro lado, técnicas y recursos literarios como la personificación y la cosificación, el humor negro, la animalización y la caricatura, el collage y la mutilación, los objetos sacados de contexto, los símbolos, etc., se encuentran en estos textos de forma abrumadora y responden todos ellos a la estética surreal.

De este modo, parece incuestionable el rasgo surrealista y vanguardista de estos relatos, que, tal como los define el autor, «tienen [...] algo de divertimiento, algo de disparate» (12). Los cuentitos recuerdan, por el ingrediente sobrenatural, la ingenuidad y la gran visualidad de las secuencias, a los cuentos tradicionales infantiles, aunque con un sesgo poético y una hondura de la que estos carecen en general.

En otro orden de cuestiones, si bien es cierto que el autor asume la estética de moda de la época en que se escribió, también lo es el hecho de que Muñoz Rojas, en tanto escritor de su tiempo, aporta un sello único, no pareciéndose a ninguno de sus contemporáneos. Por la nota irracionalista y disparatada se acerca en algunos momentos a Gómez de la Serna, sobre todo en lo que concierne a la creación de greguerías y al humor, pero se aleja de este por la gran profundidad del pensamiento que subyace en la mayoría de relatos. Asimismo, si nos atenemos solo a la sencillez expresiva, se aparta del estilo intelectualista y barroco de un Benjamín Jarnés, pero, 
también, del automatismo verbal de José Hinojosa, aunque, como es lógico, presente técnicas, motivos y temáticas similares.

Todo ello redunda en una obra personalísima, que resulta una rara avis en el panorama literario espańol y merece ser recordada, estudiada y rescatada del olvido.

Recibido: junio de 2020; ACEPTAdo: abril de 2021 


\section{BIBLIOGRAFÍA}

Bodini, Vittorio (1982): Poetas surrealistas españoles, Barcelona: Tusquets.

Bousoño, Carlos (1968): La poesía de Vicente Aleixandre, Madrid: Gredos.

Breton, André y Paul Éluard (1933): «Enquète», Minotaure I, 3-4: 101.

Díez de Revenga, Francisco Javier (2005): Poetas y narradores. La narrativa breve en las revistas de vanguardia en España (1918-1936), Madrid: Devenir Ensayo.

Ilie, Paul (1982): Los surrealistas españoles, Madrid: Taurus.

LuCAs, Antonio (2009): «Visitador de la extrañeza», El Mundo (actualizado 09/10/2014 22:06 horas).

Muñoz Rojas, José Antonio (1957): Las musarañas, Madrid: Revista de Occidente.

Muñoz Rojas, José Antonio (1979): Cuentos surrealistas, Madrid: Turner.

Ortiz, Fernando (1982): "José Antonio Muñoz Rojas, poeta en verso y prosa», La estirpe de Bécquer, Jerez de la Frontera: Ayuntamiento, 121-134.

Pedraza, Felipe y Milagros Rodríguez (2005): Manual de literatura española. XII. Posguerra: Introducción, líricos, Pamplona: Cénlit.

Raymond, Marcel (1983): De Baudelaire al Surrealismo, México: Fondo de Cultura Económica.

Ruiz-Copete, Juan de Dios (2001): «Coda para un prosista de excepción: José Antonio Muñoz Rojas», Narradores Andaluces de Posguerra, Sevilla: Universidad de Sevilla, 159-173.

SÁnchez Vidal, Agustín (1982): «Extrañamiento e identidad de "su majestad el yo" al "éxtasis de los objetos"», en Víctor García de la Concha (ed.), El Surrealismo, Madrid: Taurus, 50-73. 